\title{
EL DERECHO DE RESPUESTA, RÉPLICA, RECTIFICACIÓN EL PÚBLICO, LA INFORMACION Y LOS MEDIOS. ELIEL C.BALLESTER. EDITORIAL ASTREA DE ALFREDO Y RICARDO DEPALMA. BUENOS AIRES. 1987. 230 PAGINAS
}

\author{
Sergio Peña Neira
}

El autor en forma clara y profunda expone un tema que toca diversos órdenes del conocimiento jurídico.

Se hace necesario, sin embargo, indicar el supuesto sobre el que discurre este texto, y este no es otro que se emita en un periódico, en un diario o, en general, a través de un medio de prensa, una noticia falsa o errónea respecto de alguien. De inmediato el que se sienta aludido o afectado buscará contestar a través del mismo medio los descargos con lo que impedirá habladurías, maledicencias o que incluso se le pueda llevar a proceso. Ello, visto desde una perspectiva más general, analiza el problema de la colisión de dos derechos, a saber, la libertad de prensa y el derecho a la honra.

No busco aquí señalar todas las normas jurídicas que este interesante tema puede atravesar. Es indudable la importancia de esta materia, para el Derecho constitucional, el Derecho penal, el Derecho civil y esa nueva área que son los Derechos Humanos. Tiene especial relevancia en la responsabilidad jurídica que cabe a quienes transgredan estas normas ya que habrá de determinarse cómo el ordenamiento jurídico exige respecto a la libertad de prensa y sanciona el abuso de la misma.

El libro, en siete capítulos analiza diferentes materias que son de real atingencia a propósito del tema. En el capítulo primero, luego de los orígenes y desarrollo se estudia el concepto y la naturaleza jurídica. En cuanto a este último, existen cuatro formas de observarla. Así puede ser vista desde el Derecho penal como parte de los delitos contra el honor en el cual, de acuerdo al autor y citando a Portalis a propósito de un proyecto de la ley en el siglo pasado, se puede pedir rectificación incluso en caso de que los escritos no sean delictuosos (p.5.). Asimismo, en el Derecho administrativo el tema se ve a propósito de la libertad de prensa (protección de la verdad y el honor) (p.7.). En el ámbito civil la naturaleza de este derecho se encuentra en la reparación del daño emergente (p.7.) y, por último, en materia política se considera un derecho personalísimo.

Del mismo modo se estudian los fundamentos del Derecho de rectificación que pueden encontrarse en la libertad de información en el derecho de la información, el derecho a la comunicación y en la igualdad de oportunidades. Cada uno de ellos puede servir de base. Nos inclinamos por la idea de igualdad de oportunidades entre quienes emiten una noticia falsa o errónea y aquel que es afectado por ella. Es un hecho que el medio de comunicación puede llevar a destruir la imagen de una persona y ella buscará protegerse a través del derecho que le otorgue la ley. 
Diversas son, asimismo, las razones con las cuales los medios de prensa pueden impedir la publicación. Dichos motivos son abordados por el autor en forma clara y directa.

El capítulo segundo trata de la "reglamentación del Derecho de respuesta en materia de prensa". Nos interesa resaltar allí, para el sólo estudio doctrinario y no para el estudio de Derecho comparado, la terminología o nombre del derecho. Claramente se analiza y se concluye que es "Derecho de respuesta" el nombre que tiene una mejor connotación respecto del tema. Luego, en el mismo capítulo, se abordan diversos aspectos de importancia no menos fundamental, así, el sujeto activo del derecho del pasivo, la forma de la respuesta, la materia sobre la que debe versar y la situación en que el medio se niegue a difundir dicha respuesta que genera un juicio.

El capítulo tercero del "Derecho de rectificación de los funcionarios públicos". Aquí cabe señalar que la rectificación permite al funcionario, de acuerdo al autor, "defender la identidad de los actos de la Administración Pública, ya propios de él, ya del área de su responsabilidad. En suma, la imagen oficia" (p.127). Creemos que no sólo protegería dicha imagen.

Dicho concepto se define a través de este sistema pero, en caso de imputación de un delito a un funcionario público, este derecho defiende a la Administración Pública en su globalidad. En efecto, así, a través de la rectificación del funcionario, se podrá determinar la veracidad de la afirmación y de no existir tal rectificación corresponde a los tribunales y a la Contraloría General de la República (en Chile) determinar responsabilidades.

En el capítulo cuarto amplia el tema a la radio y la televisión, y a la cinematografía. Antes se había discernido sólo la base del periódico como medio de prensa. argentina.

El capítulo quinto apunta a la rectificación internacional y el sexto a la legislación

En fin, un texto que expone, sintetiza, reúne material y ayuda a comprender una institución que debe mantenerse en cualquier ley que trate el tema.

De otra manera tendremos frente a nosotros el abuso de difícil sanción ya que cuando se ha causado un daño a la imagen es difícil repararlo por la prensa y se corrobora con ejemplos históricos en nuestro país y en el extranjero.

Ello, por supuesto, sin impedir el que la información pueda fluir. Orden y libertad en un área que de suyo es delicada como el derecho y la honra y la libertad de información permiten una real defensa de la dignidad de la persona. 